\title{
広 報
}

\section{会務 報 告}

\section{常任理事会}

8 月 3 日(土） 3 時〜 5 時 [東大教育学部]

芝理事長, 天野, 東, 藤原, 野吕, 坂野各常任理事, 井上事務局長, 䋶纈, 松崎両嘱託出席。

I 1985年 4 月 6 月 会計報告

井上事務局長から, 資料の説明, 報告があり了承され た。

\section{II 新入会員審查}

36名の入会希望者があり，全員承認された。

III 第12回研究委員会新委員人選について

第27回総会における座長, シンポジウムの司会者, 提 案者, 指定討論者の中から次の 3 名を選出した。

（敬称略アルファペット順）

三浦香苗, 田畑 治, 寺田 晃

IV 研究委員会規定の改定について

研究委員会の今後の在り方について検討し, 新規定案 を作成した。そのとり扱いについては，次回以降の理事 会で，審議することになった。

$\mathrm{V}$ 第27回総会, 会務総会次第の報告分担について, 報 告分担者を決めた。

\section{常任編集委員会}

9 月 7 日(土） 5 時～ 8 時 30 分 [学士会分館]

藤永委員長, 福沢, 古畑, 花沢, 茨木, 鹿姉, 久世, 無藤, 小川, 岡, 佐伯, 坂野, 繁桝, 高橋, 氏森各委 員, 本庄, 䋶纈両嘱託出席。

21論文を審查した〔採択(1)，小修正採択(3)，修正採択 (7)，修正再審查(5)，原著加資料として書き值し，修正 再審查(1), 不採択(4)]

\section{第28回総会開催公告}

日本教育心理学会第 28 回総会は 1986 年10月 3 日 (金)から5 日（日）までの 3 日間, 九州大学の主催 により開催されます。

\section{合評会のおしらせ}

下記のとおり教育心理学研究第33巻第 3 号の合評会を 開催いたしますのでふるって御参加くださるようお願い 致します。

北海道地区 世話人 佐藤公治氏にお問合せ下さい

函館地区 1985年12月21日（土） 1 時30分から 北教大函館分校教育心理学第 3 実験室 世話人 鈴木正義氏

仙台地区 世話人 野吕正氏にお問合せ下さい 筑波地区 1985年9月20日(金) 5 時15分から 筑波大学人間学系棟A 202 世話人 田中 敏氏

東海地区 世話人 石田勢津子氏にお問合せ下さい 長野地区 世話人 田上不二夫氏にお問合せ下さい 近畿地区 1985年11月30日(土） 2 時から 関西大学文学部「心理第 2 実験室」 世話人 松村暢隆氏

中国地区世話人 有馬道久氏にお問合せ下さい 徳島地区 1986年1月21日(火) 10時 鳴門教育大学基礎心理学実験室 世話人 松田文子氏

福 岡 地区 世話人 持留英世氏にお問合せ下さい

\section{お 知 ら世}

毎年，国際心理学会議記念基金で，運営委員会規約に基づき次の事業を行っています。

(1) 国際交流を目的とする人物の派遣および招聘

(2) 国際交流を目的とする会議等の催しの実施ならびに援助

(3) 心理学の国際交流に必要な資料の作成収集交換ならびに頒布

来年度も 150 万队门の予算で事業を行う予定であり従来の例では外国の有力な研究者の学会大会等における講演 のための招聘が多く,その場合は往復エコノミークラスの旅費, および約 3 日分の滞在費を基金から支出されます。 この基金の援助で招聘したい研究者がありましたら至急本学会事務局までお知らせ下さい。

\section{正 誤 表}

\begin{tabular}{|c|c|c|c|c|c|}
\hline 第33巻 2 号 & 頁 & $5 \omega$ & 行 & 誤 & 正 \\
\hline \multirow[t]{3}{*}{ 石黒広昭論文 } & 139 & TABLE 3 & 表上 9 & 貸してあげた & 貸せてあげた \\
\hline & 141 & TABLE 5 & Note の下 2 & $\begin{array}{l}\text { decide point of } \\
\text { view the preference }\end{array}$ & $\begin{array}{l}\text { decide the point } \\
\text { of view preference }\end{array}$ \\
\hline & 144 & 右 & 上 20 & が態度・意図…... & 態度・意困…... \\
\hline
\end{tabular}

